\title{
BOBOT AKHIR PERSENTASE KARKAS DAN LEMAK ABDOMINAL AYAM BROILER DENGAN PEMBERIAN EKSTRAK DAUN SIRIH (Piper betle L.) DALAM AIR MINUM
}

\author{
Resa Pahlepi ${ }^{1}$, Harapin Hafid ${ }^{2}$, Amiluddin Indi $^{2}$ \\ ${ }^{1)}$ Alumnus Fakultas Peternakan UHO \\ ${ }^{2)}$ Staf Pengajar Fakultas Peternakan UHO \\ e-mail : harapinhafid@yahoo.co.id
}

\begin{abstract}
ABSTRAK
Penelitian ini dilakukan untuk mengetahui efek dari penambahan ekstrak daun sirih (Piper betle $L$ ) dalam air minum terhadap bobot akhir persentase karkas dan lemak abdominal ayam broiler. Materi yang digunakan pada penelitian ini adalah 80 ekor ayam broiler strain SR-707 yang dipelihara selama 5 minggu. Ayam penelitian dibagi dalam 20 petak kandang dengan lima perlakuan dan empat pengulangan yang masing-masing petak diisi dengan 4 ekor ayam percobaan. Air minum perlakuan yang diberikan terdiri atas: P1= kontrol, P2 (Air minum + ekstrak daun sirih 0,5\%), P3(Air minum + ekstrak daun sirih 1\%), P4 (Air minum + ekstrak daun sirih 1,5\%), P5 (Air minum + ekstrak daun sirih 2\%). Parameter yang diamati adalah bobot akhir, persentase karkas, lemak abdominal ayam broiler umur 5 minggu. Data yang diperoleh diolah dan dianalisis berdasarkan prosedur sidik ragam dan di uji dengan uji-F. Hasil penelitian menunjukkan bahwa penambahan ekstrak daun sirih dalam air minum berpengaruh tidak nyata $(p>0,05)$ terhadap bobot akhir, persentase karkas dan lemak abdominal ayam brolier. Kesimpulan yang di peroleh dalam penelitian ini adalah bahwa penggunaan ekstrak daun sirih sampai pada level $2 \%$ dalam air minum tidak berpengaruh terhadap bobot akhir, persentase karkas dan lemak abdominal ayam broiler yang dipotong pada umur lima minggu.
\end{abstract}

Kata kunci: Bobot akhir, Persentase karkas, lemak abdominal, daun sirih, broiler.

\begin{abstract}
This study aims to know the effect of (Piper betle L.) leaves extract addition in drinking water on carcass percentage and abdominal fat of broiler chicken. Experimental material was used to this study were eighty broiler chicken SR-707. Broiler chicken was divided into twenty pen with five treatments and four replications and each pen was filled with four broiler chickens. The treatments were $\mathrm{P} 1=$ drinking water without betel leaves extract, $\mathrm{P} 2=$ drinking water $+0,5 \%$ extract of betel leaves, $\mathrm{P} 3=$ drinking water $+1 \%$ extract of betel leaves, $\mathrm{P} 4$ drinking water $+1,5 \%$ betel leaves extract, and P5 $=$ drinking water $+2 \%$ betel leaves extract. variables were final weight, carcass percentage and abdominal fat of 5 weeks broiler chicken. The data obtained was processed and analyzed using analysis variance and continued using F-test. The result showed that addition of betel leaves extract in drinking water did not give significant $(\mathrm{P}>0,05)$ effect on final weight, carcass percentage and abdominal fat of broiler chicken. The conclusion was using betel leaves extract untill $2 \%$ in broiler drinking water no decreased final weight, carcass percentage and abdominal fat of broiler chicken that was slaughtered at 5 weeks of old.
\end{abstract}

Key words: Final Weight, Carcass percentage, abdominal fat, Piper betle L, Broiler

${ }^{*)}$ Corresponding authors 


\section{PENDAHULUAN}

Kebutuhan daging ayam broiler diperlukan manusia sebagai sumber protein. Protein hewani menjadi sangat penting karena mengandung asam-asam amino yang mendekati susunan asam amino yang dibutuhkan manusia sehingga lebih mudah dicerna dan lebih efisien pemanfaatannya. Ayam broiler memiliki kelebihan diantaranya dagingnya empuk, ukuran badan besar, bentuk dad lebar, padat dan berisi, efisiensi terhadap pakan cukup tinggi (SUPRIJATNA, 2006). Namun, keberadaan residu antibiotika dalam daging yang tidak diketahui manusia dapat mengakibatkan berbagai ancaman seperti terjadinya penyakit yang dapat membahayakan kesehatan.

Penggunaan antibiotika merupakan salah satu cara yang biasa dilakukan peternak untuk mengembalikan kondisi ternak dalam keadaan normal. Selain itu, pemakaian antibiotik dalam pakan dan air minum dimaksudkan untuk mempercepat pertumbuhan ternak serta meningkatkan hasil produksi ternak (LEVY, 1998 dan BURCH, 2000). Antibiotika dapat dikelompokkan berdasarkan struktur antibiotika tersebut ataupun berdasarkan target kerjanya pada sel yaitu, spektrum luas (broad spectrum) yang mempunyai kemampuan membunuh mikroorganisme dari berbagai spesies dan spektrum sempit (narrow spectrum) yang hanya mampu membunuh mikroorganisme secara spesifik.

Akan tetapi penggunaan antibiotika secara terus-menerus dapat mengakibatkan sistem kekebalan tubuh ternak menjadi lemah dan rentan terhadap penyakit, selain itu residu yang ditinggalkan dalam daging broiler akibat penggunaan antibiotik dapat membahayakan kesehatan manusia yang mengkonsumsinya. Oleh karena itu, antibiotik yang berasal dari tanaman herbal sangat diperlukan sebagai alternatif untuk mencegah adanya residu dalam daging ayam broiler.
Daun sirih (Piper betle L.) diharapkan dapat menjadi alternatif untuk menggantikan antibiotik sintetik yang dapat menimbulkan residu dalam tubuh. Terdapat banyak zat yang baik untuk kesehatan yang terkandung dalam daun sirih terutama yang telah diproses dan diambil minyaknya. Minyak atsiri yang berasal dari daun sirih mengandung butyiphenol, seskuiterpen, pati, diatase, gula dan kavikol (senyawa yang memiliki kekuatan untuk membunuh kuman), antioksidasi dan fungisida, serta anti jamur. Lebih lanjut (DARWIS, 1992 dan IRIANTI, 2008) menyatakan bahwa kandungan minyak atsiri yang terdapat dalam daun sirih terdiri atas: allilkatekol 2.7-4.6\%, kadinen $6.7-9.1 \%$, karvakol $2.2-4.8 \%$, karyofilen $6.2-11.9 \%$, kavibetol $0.0-1.2 \%$, kavikol 5.1-8.2\%, sineol dan eugenol metileter $8.2-15.8 \%$ dan juga mengandung pirokatekin. Selain itu daun sirih segar mengandung senyawa fenolik, dimana senyawa ini memiliki sifat antimikroba atau menghambat pertumbuhan mikroba (LINDAWATY, 1997; NURUL dan ADITYA, 2010). Senyawa-senyawa ini diharapkan dapat meningkatkan sistem kekebalan tubuh ayam broiler dan dapat meningkatkan persentase karkas dan menurunkan persentase lemak abdominal yang dihasilkan.

Laju pertumbuhan dan bobot badan akhir ayam berhubungan erat dengan bobot karkas dan lemak abdominal yang dihasilkan (MUGIYONO, 2001). Kualitas karkas dipengaruhi oleh banyak faktor salah satunya adalah lemak. Kelebihan energi asal lemak akan disimpan pada bagian subcutan dan rongga perut (lemak abdominal). Lemak abdominal sangat erat hubungannya dengan bobot karkas, jika lemak abdominal tinggi maka bobot karkas akan rendah karena adanya energi yang berlebih sehingga terjadi penimbunan lemak abdominal demikian pula sebaliknya. Penggunaan daun sirih sebagai antibiotik herbal diharapkan mampu meningkatkan persentase karkas dan menurunkan persentase lemak abdominal 
ayam broiler yang diberi ransum basal. Oleh karena itu, perlu dilakukan penelitian tentang penggunaan ekstrak daun sirih dalam air minum terhadap bobot hidup persentase karkas dan lemak abdominal ayam broiler.

\section{MATERI DAN METODE}

Penelitian ini telah dilaksanakan pada bulan April sampai Mei 2013, bertempat di Kandang ternak Unggas Fakultas Peternakan Universitas Haluoleo Kendari.

Pembuatan ekstrak daun sirih dilakukan dengan mengambil bagian daun dari tanaman sirih sebanyak 50 gram yang kemudian dicacah dan direndam dalam air yang bersuhu $30{ }^{0} \mathrm{C}$ selama \pm 5 menit. Kemudian daun sirih dihancurkan dengan menggunakan blender dengan perbandingan air dan daun 1:2 sehingga diperoleh jus daun sirih. Untuk mendapatkan ekstrak daun sirih, maka jus daun sirih disaring untuk menghilangkan filtrat dan di gunakan sebagai ekstrak kemudian langsung dicampurkan ke air minum ayam broiler.

Rancangan yang digunakan adalah Rancangan Acak Lengkap yang terdiri atas 5 perlakuan dengan 4 ulangan, sehingga terdapat 20 unit percobaan. Masingmasing unit berisi 4 ekor ayam broiler SR707. Pakan dan air minum diberikan secara ad libitum, penimbangan sisa pakan dilakukan setiap minggu. Sedangkan air minum diganti sebanyak 2 kjali setiap hari. diberiPerlakuan yang dicobakan yaitu: P1 = Air minum tanpa ekstrak daun sirih (kontrol), $\mathrm{P} 2=$ Air minum + ekstrak daun sirih $0,5 \%, \mathrm{P} 3=$ Air minum + ekstrak daun sirih $1 \%, \mathrm{P} 4=$ Air minum + ekstrak daun sirih $1,5 \%$ dan P5 = Air minum + ekstrak daun sirih $2 \%$.

koleksi karkas dilakukan dengan cara menimbang bobot hidup kemudian ayam dipotong pada leher hingga terpotong saluran penapasan, pencernaan dan pembuluh darah. Setelah ayam benarbenar mati, selanjutnya dilakukan pencabutan bulu dengan cara merendam terlebih dahulu ke dalam air dengan suhu $70{ }^{\circ} \mathrm{C}$ selama 30 detik. Kemudian kepala dan kedua kaki dipotong serta dikeluarkan isi dalam ayam percobaan, lalu ditimbang bagian karkasnya. Lemak abdominal diperoleh dari lemak yang menempel pada dinding perut (abdomen), selanjutnya ditimbang untuk mengetahui berat lemak tersebut.

Variabel yang diamati adalah:

1. Bobot Akhir $=$ Bobot akhir didapatkan melalui penimbangan seluruh ayam kemudian dirata-ratakan.

2. Persentase Berat Karkas $(\%)=$ $\frac{\text { Bobot Karkas (g) }}{\text { Bobot Hidup (g) }} \times 100 \%$

3. Persentase Lemak Abdominal $(\%)=$ $\frac{\text { Berat lemak Abdominal (g) }}{\text { Bobot Karkas (g) }}$ X $100 \%$

\section{HASIL dan PEMBAHASAN}

\section{Bobot Akhir}

Bobot akhir (gram) diperoleh dari hasil penimbangan ayam sebelum dipotong dan setelah dipuasakan. Rataan bobot akhir selanjutnya dapat dilihat pada Tabel 2

Tabel 2. Rataan bobot hidup ayam broiler dalam penelitian (gr)

\begin{tabular}{ccccccc}
\hline \multirow{2}{*}{ Ulangan } & \multicolumn{5}{c}{ Perlakuan } & \multirow{2}{*}{ Total } \\
\cline { 2 - 6 } & P1 & P2 & P3 & P4 & P5 & \\
\hline 1 & 2085 & 1998 & 1925 & 1946 & 2127 & 10081 \\
2 & 2000 & 2017 & 2171 & 2226 & 2048 & 10462 \\
3 & 1774 & 1980 & 1901 & 1980 & 2044 & 9679 \\
4 & 2065 & 1999 & 1971 & 2257 & 2085 & 10377 \\
\hline Total & 7924 & 7994 & 7968 & 8409 & 8304 & 40599 \\
\hline Rata-Rata & 1981 & 1998.5 & 1992 & 2102.25 & 2076 & 2029.95 \\
& $\pm 142,7$ & $\pm 15,11$ & $\pm 122,82$ & $\pm 161,9$ & $\pm 38,7$ & \\
\hline
\end{tabular}


Berdasarkan perhitungan statistik dengan analisis sidik ragam, tidak terdapat perbedaan yang nyata $(p>0,05)$ antara bobot hidup akhir dengan penambahan ekstrak daun sirih sampai level $2 \%$ dalam air minum. Apabila dilihat dari tabel 2 maka rataan bobot akhir tertinggi sampai terendah adalah P4, P5, P2, P3 dan P1 (2102,25 gr/ekor, 2076 gr/ekor, 1998,5 gr/ekor, 1992 gr/ekor dan 1981 gr/ekor). tidak adanya perbedaan yang nyata kemungkinan disebabkan keseragaman dari segi pemeliharaan seperti pengelompokkan ayam dengan jumlah yang sama, pemberian ransum dengan kadar nutrisi yang sama dan kondisi lingkungan yang sama seperti suhu. Lingkungan merupakan faktor yang paling berpengaruh terhadap bobot hidup, lingkungan yang sesuai dibutuhkan ayam broiler agar proses metabolisme tubuhnya dapat berjalan dengan optimal (Fijana, 2012). Bobot badan akhir juga dipengaruhi oleh pertambahan bobot badan dan konsumsi ransum. Anggorodi (2004) menyatakan bahwa salah satu faktor yang berperan penting dalam mempengaruhi laju pertumbuhan adalah konsumsi ransum.
Bobot hidup yang dihasilkan dalam penelitian erat kaitannya dengan kecepatan pertumbuhan ayam broiler dan bobot karkas yang dihasilkan. Pertumbuhan ayam broiler secara optimal terjadi pada umur 4 - 6 minggu, karena ketika memasuki umur $7-8$ minggu pertambahan bobot badan broiler per minggu merosot dan tidak seimbang antara pertumbuhan dengan makin meningkatnya pakan yang dikonsumsi, yang mengakibatkan efisiensi pakan menjadi rendah, sehingga lebih menguntungkan apabila broiler dijual lebih awal. Faktor lain yang harus dipertimbangkan adalah kegemaran konsumen disuatu daerah, dimana pada daerah tertentu konsumen lebih suka ayam broiler dengan berat kurang dari $1 \mathrm{~kg}$, sementara didaerah lain konsumen lebih suka ayam broiler dengan berat $1,5-2 \mathrm{~kg}$ hingga diatas $2 \mathrm{~kg}$ (Komara, 2009).

\section{Persentase Karkas}

Persentase karkas diperoleh dari perbandingan antara berat karkas dan berat hidup dikalikan $100 \%$. Rataan persentase karkas dalam penelitian ini dapat dilihat pada Tabel 3.

Tabel 3. Rataan Persentase Karkas Broiler dengan Pemberian Ekstrak Daun Sirih Dalam Air Minum

\begin{tabular}{|c|c|c|c|c|c|c|}
\hline \multirow{2}{*}{ Ulangan } & \multicolumn{5}{|c|}{ Perlakuan } & \multirow{2}{*}{ Total } \\
\hline & $\mathrm{P} 1$ & $\mathrm{P} 2$ & P3 & $\mathrm{P} 4$ & P5 & \\
\hline 1 & 71.56 & 73.17 & 73.25 & 71.63 & 72.49 & 362.1 \\
\hline 2 & 71.35 & 73.72 & 70.84 & 73.45 & 69.77 & 359.13 \\
\hline 3 & 69.5 & 69.8 & 72.49 & 72.56 & 69.47 & 353.82 \\
\hline 4 & 71.48 & 71.89 & 71.18 & 71.02 & 72.03 & 357.6 \\
\hline Total & 283.89 & 288.58 & 287.76 & 288.66 & 283.76 & 1432.65 \\
\hline Rata-Rata & $\begin{array}{c}70.97 \\
\pm 0.99\end{array}$ & $\begin{array}{c}72.14 \\
\pm 1.74\end{array}$ & $\begin{array}{r}71.94 \\
\pm 1.13\end{array}$ & $\begin{array}{r}72.16 \\
\pm 1.07\end{array}$ & $\begin{array}{l}70.94 \\
\pm 1.54\end{array}$ & 71.63 \\
\hline
\end{tabular}

Berdasarkan hasil analisis ragam menunjukkan bahwa pemberian ekstrak daun sirih dengan level $0,5 \%$ sampai $2 \%$ dalam air minum tidak berpengaruh nyata $(p>0,05)$ terhadap persentase karkas broiler umur 5 minggu. Apabila dilihat pada Tabel 2 maka rataan persentase karkas dari tertinggi sampai terendah 
adalah P4 (72,16\%), P2 (72,14\%), P3 Hal ini kemungkinan disebabkan bahwa pemberian ekstrak daun sirih sampai $2 \%$ tidak memberikan respon pertumbuhan terhadap persentase karkas sehingga persentase karkas broiler yang diperoleh tidak berbeda signifikan. Selain itu, tidak adanya perbedaan yang nyata disebabkan karena penambahan ekstrak daun sirih dalam air minum juga memberikan pengaruh yang tidak berbeda nyata terhadap bobot hidup ayam broiler.

Tingginya bobot karkas ditunjang oleh bobot hidup akhir sebagai akibat pertambahan bobot hidup ternak bersangkutan. Peningkatan bobot karkas dipengaruhi juga oleh konsumsi pakan, semakin tinggi konsumsi pakan maka pertambahan bobot badan yang tinggi sehingga bobot karkas yang diperoleh juga tinggi dan sebaliknya. Kandungan minyak atsiri daun sirih tidak mempengaruhi persentase karkas ayam broiler, akan tetapi mampu meningkatkan kekebalan tubuh

Rataan persentase bobot karkas ayam boiler umur 5 minggu penelitian ini berkisar 70,94 - 72,16\% , angka tersebut berbeda lebih tinggi dengan hasil
(71,94\%), P1 (70,97\%) dan P5 (70,94\%). penelitian Akhadiarto (2010), yakni 57,39 $60,08 \%$ dan hasil penelitian BESTARI (2005) yakni 61,09 - 66,35\%. Sedangkan hasil penelitian Mahfudz (2009), menyatakan persentase karkas bagian tubuh ayam broiler berkisar antara $65-75 \%$ dari bobot hidupnya. Selain dipengaruhi bobot badan dan konsumsi pakan yang tinggi, persentase karkas juga dipengaruhi jenis kelamin ayam yang dipotong.

\section{Persentase Lemak Abdominal}

Lemak abdominal merupakan salah satu komponen lemak tubuh ayam yang terdapat pada rongga perut. Lemak adominal didapat dari lapisan yang membungkus organ pencernaan. Persentase lemak abdominal diperoleh berdasarkan hasil pembagian bobot lemak abdominal dengan bobot karkas dikalikan $100 \%$. Rataan persentase lemak abdominal dengan pemberian ekstrak daun sirih dalam air minum ayam broiler yang dilakukan selama 5 minggu dapat dilihat pada Tabel 4

Tabel 4. Rataan persentase lemak abdominal broiler yang diberi ekstrak daun sirih dalam air minum

\begin{tabular}{ccccccc}
\hline \multirow{2}{*}{ Ulangan } & \multicolumn{5}{c}{ Perlakuan } & \multirow{2}{*}{ Total } \\
\cline { 2 - 6 } & $\mathrm{P} 1$ & $\mathrm{P} 2$ & $\mathrm{P} 3$ & $\mathrm{P} 4$ & $\mathrm{P} 5$ & \\
\hline 1 & 1.67 & 2.19 & 2.55 & 1.36 & 2.01 & 9.78 \\
2 & 1.47 & 2.69 & 1.76 & 2.01 & 3.57 & 11.5 \\
3 & 2.51 & 1.74 & 2.54 & 2.64 & 1.76 & 11.19 \\
4 & 1.76 & 1.53 & 2.28 & 3.18 & 1.53 & 10.28 \\
\hline Total & 7.41 & 8.15 & 9.13 & 9.19 & 8.87 & 42.75 \\
\hline Rata-Rata & 1.85 & 2.03 & 2.28 & 2.29 & 2.21 & 2.14 \\
& \pm 0.45 & \pm 0.51 & \pm 0.37 & \pm 0.79 & \pm 0.92 & \\
\hline
\end{tabular}

Keterangan: $\mathrm{P} 1=$ Kontrol, $\mathrm{P} 2=$ ekstrak daun sirih $0,5 \%, \mathrm{P} 3=$ ekstrak daun sirih 1\%, P4= ekstrak daun sirih $1,5 \%$ dan $\mathrm{P} 5=$ ekstrak daun sirih $2 \%$. 
Berdasarkan analisis sidik ragam menunjukkan bahwa pemberian ektstrak daun sirih dalam air minum broiler tidak berpengaruh nyata $(p>0,05)$ terhadap persentase lemak abdominal broiler. Apabila dilihat pada Tabel 3 maka rataan persentase lemak abdominal broiler dari tertinggi sampai terendah adalah $\mathrm{P} 4$ (2,29\%), P3 (2,28\%), P5 (2,21\%), P2 $(2,03 \%)$ dan P1 (1,85\%). Hal ini kemungkinan disebabkan karena pakan yang diberikan pada setiap perlakuan merupakan pakan komersil yang kandungan energi metabolisnya sama, sehingga pembentukan lemak yang terjadi tidak berbeda nyata pada setiap perlakuan.

Hasil penelitian ini menunjukkan bahwa rataan persentase lemak abdominal yang diperoleh adalah 1,85 - 2,29\% dan berbeda dengan hasil penelitian SETIAWAN dan SUJANA (2009) yakni berkisar 2,24 $3,90 \%$. SYZKA (2009) menyatakan bahwa akumulasi total lemak abdominal dan penyebarannya pada bagian-bagian tubuh ayam pedaging dipengaruhi oleh pakan. SETIAWAN dan SUJANA (2009) menambahkan bahwa pembentukan lemak pada ayam broiler meningkat pada umur lima minggu, sementara umur 21 sampai umur 33 hari relativ masih rendah yakni 2,22 - 3,19\% dari bobot badan. Dalam kondisi umur tersebut keberadaan lemak abdominal belum terlalu banyak terbentuk karena zat-zat makanan diserap oleh tubuh masih digunakan untuk pertumbuhan. Penimbunan lemak dalam rongga perut ayam terjadi karena adanya kelebihan energi yang dikonsumsi sehingga melebihi kebutuhan untuk metabolisme tubuh secara normal. Akan tetapi SANZ (2000) menyatakan bahwa penurunan lemak abdominal merupakan salah satu hal yang menguntungkan, karena akan memperbaiki kualitas karkas dengan menghasilkan daging yang rendah lemak.

Pemberian ekstrak daun sirih dalam air minum sampai pada level $2 \%$ belum mampu membantu penyerapan lemak. Kondisi terikatnya asam empedu menyebabkan fungsi empedu untuk membantu proses penyerapan lemak akan menjadi terhambat. Selanjutnya asam empedu yang terikat akan dikeluarkan dari tubuh dalam bentuk ekskreta, sehingga mengakibatkan penurunan deposisi lemak abdomen.

Semakin tinggi persentase lemak abdominal maka akan menurunkan kualitas karkas yang dihasilkan begitu pula sebaliknya. Rataan persentase lemak tertinggi adalah P4 yakni 2,29\% dan berbanding lurus bahwa P4 menghasilkan persentase karkas paling tinggi yakni $72,16 \%$, sehingga dapat dijelaskan bahwa bobot badan ayam yang tinggi akan menghasilkan persentase karkas dan lemak abdominal yang tinggi pula.

\section{KESIMPULAN}

Berdasarkan hasil penelitian yang diperoleh, maka kesimpulan dari penelitian ini bahwa penggunaan ekstrak daun sirih sampai pada level 2\% dalam air minum tidak berpengaruh terhadap persentase karkas dan lemak abdominal ayam broiler yang dipotong pada umur lima minggu

\section{DAFTAR PUSTAKA}

Akhadiarto, S. 2010. Pengaruh pemberian probiotik temban, biovet dan biolacta terhadap persentase karkas, bobot lemak abdomen dan organ dalam ayam broiler. Pusat Teknologi Produksi Pertanian, BPPT. Jakarta

Pusat.Levy, S.B. 1998. The challenge of antibiotic resistance. Scientific American:46-53.

Anggorodi, H. R. 2004. Ilmu Makanan Ternak Umum. Gramedia, Jakarta

Bestari, J., Parakkasi, A., dan Akil, S. 2005. Pengaruh pemberian tepung daun mengkudu (morinda citrifolia linn) yang direndam air panas terhadap penampilan ayam broiler. Fakultas Pascasarjana (Seminar Nasional Teknologi 
Peternakan dan Veteriner) IPB. Bogor.

Burch, D.G.S. 2000. Antimicrobial sensitivity pattern of uk chicken e. coli isolates. paper presented at the european association of veterinary pharmacology and toxicology congress p.73c. Jerusalem, Israel.

Darwis, S.N. 1992. Potensi Sirih (Piper Betle Linn) Sebagai Tanaman Obat. Warta Tumbuhan Obat Indonesia 1 (1): 9-11.

Fijana, M.F., Supriatna, E., Atmomarsono, U. 2012. Pengaruh pemberian pakan pada siang malam hari dan pencahayaan pada malam hari terhadap produksi karkas ayam broiler. Fakultas Peternakan dan Pertanian UNDIP. Semarang.

Irianti Amin. 2008. Aplikasi ekstrak daun sirih dalam menghambat oksidasi lemak jambal pati. Institut Pertanian Bogor.

Komara, T. 2009. Kapan Waktu Yang Tepat Untuk Panen. http://tonikomara.blogspot.com/2009/02/ Diakses tanggal 17 Juli 2013.

Lindawaty, A. 1997. Identifikasi antioksidan hasil isolasi dari daun sirih. Skripsi. Fakultas

Pertanian Unila. Bandar Lampung. Hal; $6-8$.

Mahfudz, L.D., F.L. Maulana, U. Atmomarsono, T.A.Sarjana. 2009. Karkas dan lemak abdominal ayam broiler yang diberi ampas bir dalam ransum. Seminar Nasional

Kebangkitan PeternakanSemarang.

Mugiyono, S. 2001. Pengaruh campuran ransum komersil dan dedak padi yang ditambah caco3 dan premix terhadap pertumbuhan ayam kampung periode starter. J. Agrisistem. 2 (1): 17 - 25

Nurul Rahmah, Aditya Rahman KN. 2010. Uji fungistatik ekstrak daun sirih (piper betle 1.) terhadap candida albican. Bioscientiae Volume 7, Nomor 2, Halaman 17- 24.

Setiawan, I. dan Sujanan, E. 2009. Bobot Akhir, Persentase karkas dan lemak abdominal ayam broiler yang dipanen pada umur yang berbeda. Fakultas Peternakan. Universitas Padjajaran.

Suprijatna, E,. 2006. Ilmu Dasar Ternak Unggas. Penebar Swadaya. Jakarta.

Sanz, M. A. Flores, C. J. Lopez-Bete and J.M. Carmora, 2000. Effect of the inclusion time of dietary saturated and unsaturated fats before slaughter on the accumulation and composition of abdominal fat in female broiler chickens. Poultry Science, 79: 1320-1325.

Syzka, M.G., Supratman, H dan Abun. 2009. Pengaruh imbangan energi dan protein ransum terhadap bobot karkas dan bobot lemak abdominal ayam ayam pedaging umur 3-5 minggu. J. Agroland 16 (1): 105-112. 